\title{
There Were No More Roses
}

On the day I do pass away, no one shall dress in black. There will be no funeral procession; there will be no obituary; there will be but a wren on my windowsill, chirping happily where I never did. Find comfort in this if you can, for there is no comfort to be had here. These words have no rhyme; no syllable; no purpose; they are as dead as the dried blood I left for you; the only thing I ever left for you; the only thing I ever did right; left a perfect puddle where I concluded my effortless journey. Like my mouth my wrists are open, like my lips my wrists are red. I have never seen so much red before, and it almost brings a smile. It reminds me of the roses I once had and in my bodily liquid I see them again, their petals eagerly awaiting the opportunity to lick my wounds. Washed away are my troubles in the blood in the shadow of one last 'good-bye.' No note, no reason, there's none to give. If you still don't know why, like you didn't know then, I ain't gonna bother letting you inside to admire my cuts 
and bruises. I'm broken; I'm defeated; my life source is all but waning. I don't have the will to carry on, so I cut down deep like taking an axe to a tree, my wrists are felling and I suddenly feel again. Maybe this ain't right, maybe I am wrong, but who's going to say such things as my insides flow out around me onto my navy blue tiles? My life flashes before me, twilight's upon me and as always, you're not here. The arterial red draining from my body fills my heart with so much glee. I'm glad to be rid of the pain; of me; of you. There was never a better time to say goodbye like the present, but the words still fail to come. Like 'help' the vowels and adjectives become stuck in my throat, such alien terms gurgling down deep, frustrating me as always with their symbolism. I am glad it is over, do you feel the same? For the record, I ain't apologising, I always knew it had to be this way. I wonder if mommy will be impressed right now, she never was before. Death is the cure I've been looking for, has it been the same for you all this time? I'd ask you to join me in Purgatory, but I've been there already half my life and know it better than I know myself. I ain't going to no better place; I ain't going to no happy ending. I'm just going, and this time I promise you, I will not be coming home.

Nicholas McKay 